\title{
UCLPRESS
}

Article title: Phanerozoic Climate and Vertical Tectonic Cycles

Authors: james croll

License information: This is an open access article distributed under the terms of the Creative Commons Attribution License (CC BY) 4.0 https://creativecommons.org/licenses/by/4.0/, which permits unrestricted use, distribution and reproduction in any medium, provided the original author and source are credited.

Preprint statement: This article is a preprint and has not been peer-reviewed, under consideration and submitted to UCL Open: Environment for open peer review.

DOI: $10.14324 / 111.444 / 000009 . v 1$

Publication date: 01 February 2019

Keywords: climate, erosion, geodynamics, geothermal, hot-house, ice-house, sedimentation, subsidence, uplift, tectonics, Climate 


\section{Phanerozoic Climate and Vertical Tectonic Cycles}

James Croll FREng

Emeritus Professor of Civil Engineering

University College London

\section{ABSTRACT}

Evidence of kilometre scale uplift and subsidence at locations remote from any recognised plate boundaries, the existence of mega-sequences of post-rift marine sediments over widespread intracratonic areas, and the consideration that pulses of deposition display a clear periodicity and synchronicity over widely dispersed spatial domains, remain largely unresolved issues within current geological theory. While the exact timing of uplift and erosion associated with major unconformities are difficult to assess, the age of sediments immediately above provide vital temporal markers for the onset of subsidence and associated sea level rise. By reconsidering the much studied sedimentary sequences of the Grand and Bryce Canyon areas the following will show that the at least over the Phanerozoic eon the initiation of new pulses of deposition occur at times when earth climate is emerging from ice-house to hot-house conditions. Furthermore, the recorded periods in which global occurrences of epeirogeny have occurred will be shown to correlate closely with the end of hot-house periods and the onset of ice-house global climate conditions. Finally, some tentative thermo-geodynamic explanations for this apparent causal link between global climate and vertical tectonics will be suggested.

\section{BACKGROUND}

A recent meeting to celebrate 50 years of plate tectonic achievement ${ }^{1}$ was challenged to provide plausible explanations for the largely unresolved observations of kilometre scale, cyclic, rises and falls of continental and oceanic crust ${ }^{2}$. Furthermore, this meeting was reminded that these kilometre scale cycles of burial and exhumation exhibit synchronicity over wide spatial domains and often occur in regions where plate tectonic models suggest passive tectonic activity ${ }^{3}$. That such motions occur and so often result in major unconformities in the sedimentary sequences were the cornerstones of James Hutton's awakening of the field of geology ${ }^{4}$ in the closing decades of the $18^{\text {th }}$ C. And yet even with the undoubted advances in the field of geology over the past 50 years there still appears to be no satisfactory explanation for these processes. The following will reappraise the sedimentary records exposed within the Grand Canyon which, as Sloss ${ }^{5,6,7}$ repeatedly pointed out, display clear cycles of deposition and non-deposition reflecting kilometre scale cycles of crustal rise and fall; these cycles of deposition and non-deposition and their associated vertical motions still explanation. This reappraisal will demonstrate that phasing of the cycles of subsidence and upheaval, burial and exhumation, have a strong correlation with the ice- and hot-house cycles of climate that have occurred at periodicities of circa $130 \mathrm{Ma}$ over at least the Phanerozoic (-540 Ma to present $)^{8,9}$. Because any sedimentary records within the Grand Canyon ${ }^{10,11}$ have been lost from the early Mesozoic (-270 Ma to present) the evidence from the contiguous region of the Grand Staircase leading up to Bryce Canyon will be used to complete the analysis up to at least $-40 \mathrm{Ma}^{12}$.

\section{PHANEROZOIC CYCLES OF SEDIMENTATION}

\section{Grand Canyon Pulses of Sedimentation}

Figure 1 provides a commonly accepted summary of the sedimentary sequences exposed within the Grand Canyon ${ }^{10,11}$. As observed by Sloss ${ }^{5,6,7}$ and others these sequences exhibit a number of 
unconformities at which substantial time gaps exist between adjacent sedimentary layers. For example, the youngest sediments remaining within the "Grand Canyon Supergroup" date from -740 Ma. At some time between -740 Ma and -525 Ma this Supergroup was so deeply buried beneath megasequences of sediments that a combination of extreme heat and associated horizontal stress caused the sediments to buckle and fracture into the angular distortions now evident in the exposures at the base of the Grand Canyon. What cannot be surmised from the extant rocks is whether other cycles of subsidence, sedimentation, uplift and erosion occurred between -740 Ma and $-525 \mathrm{Ma}$. But what is certain is that at some time prior to $-525 \mathrm{Ma}$ this region experienced uplift and erosion back to an essentially horizontal, peneplain, surface before once again subsiding beneath sea level to have yet another sequence referred to as the Tonto Group laid down. Deposition of the Tonto Group commenced at $-525 \mathrm{Ma}$ and continued until at least -505 Ma and some unknown time prior to - $385 \mathrm{Ma}$ before another regional uplift and subaerial erosion resulted in the formation of a further peneplain with youngest exposed sediments of $-505 \mathrm{Ma}$. At some time prior to $-385 \mathrm{Ma}$ the region underwent a further subsidence to beneath sea level to commence deposition of the Grand Stair Group which with continuing subsidence lasted until at least -270 Ma and possibly some unknown time prior to $-265 \mathrm{Ma}$ before again experiencing regional uplift and possibly erosion. These cycles of subsidence, sedimentation, uplift and erosion are summarised in Fig A.1 to A.3 of Appendix A.

\section{Bryce Canyon Pulses of Sedimentation}

Outcrops of sediments younger than -270 Ma have been largely eroded from the area of the Grand Canyon but fortunately are still abundantly exposed in the adjacent Grand Staircase leading up to
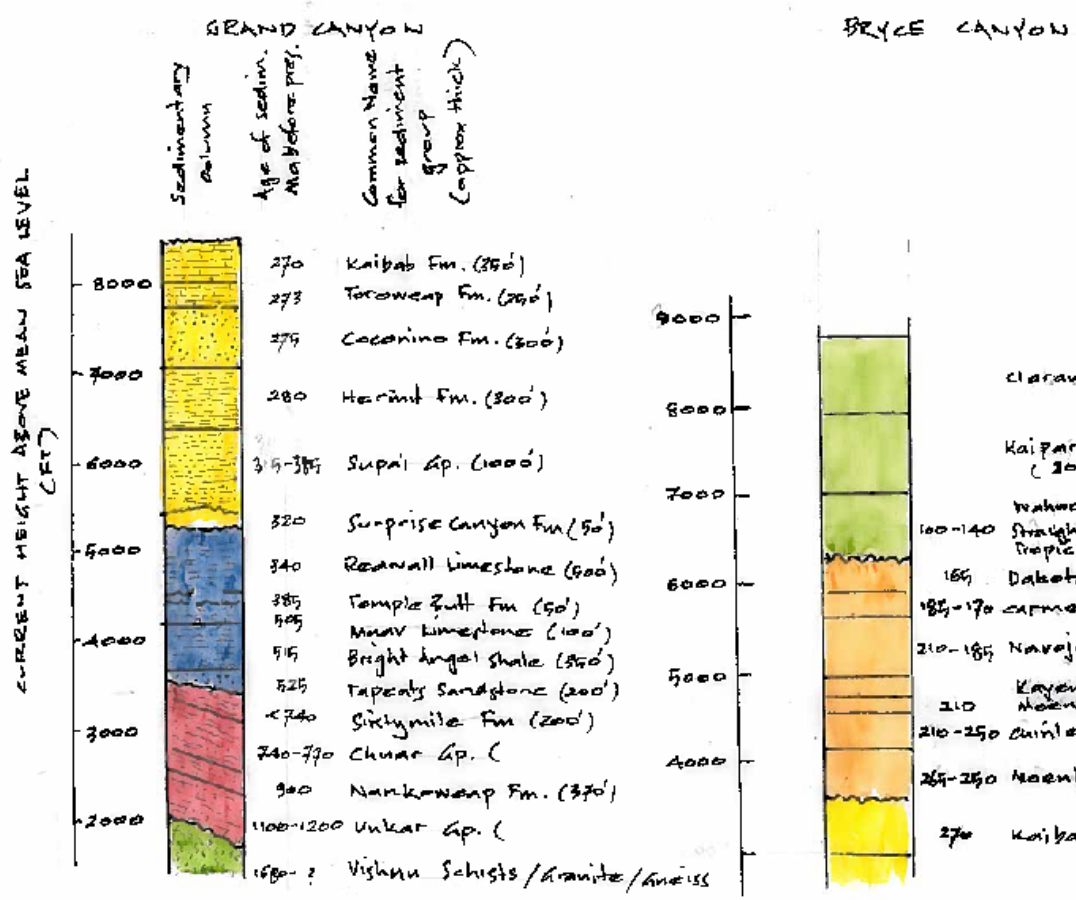

Fig 1 Typical chronology of sedimentary sequences in (a) the Grand Canyon area and the contiguous (b) Bryce Canyon region, with indicative elevations above current mean sea level.

Bryce Canyon ${ }^{12}$. The clear geological link between the Grand and Bryce Canyon regions is shown in Figure 2. These exposed sediments of the Grand Staircase are not just a spectacular tourist attraction for their rich, colourful, terraces but provide a continuing valuable record of geological 
activity for a further $230 \mathrm{Ma}$. Exhumation and any erosion at circa -270 Ma was clearly short lived and reburial at -265 Ma saw the start of deposition of further mega-sequences until sometime between -165 Ma and -140 Ma. From -165 Ma there is a gap of $25 \mathrm{Ma}$ during which both sedimentation and erosion will likely have occurred - the extent and timing of each being uncertain. But what is very clear is that from around $-140 \mathrm{Ma}$ the region commenced another extended period of subsidence coupled with the deposition of deep sedimentary sequences that now make up the top $1 \mathrm{~km}$ of the exposed Grand Staircase. These additional cycles of subsidence, sedimentation, uplift and erosion are summarised in Fig A.4 to A.5 of Appendix A. At some indeterminate time during the past $40 \mathrm{Ma}$ the whole sequence was uplifted by some $3.6 \mathrm{~km}$ in the area of Bryce Canyon and very possibly even more in the region of the Grand Canyon where the matching -270 Ma strata are currently some $3.2 \mathrm{~km}$ above the equivalent strata at Bryce Canyon. That marine sediments laid down within the past $40 \mathrm{Ma}$ in the Grand Canyon area have risen by more than $6.8 \mathrm{~km}$ and had possibly in excess of $3 \mathrm{~km}$ post $-270 \mathrm{Ma}$ sediments ground away seems highly likely given the stratigraphic record exhibited in Fig 2.

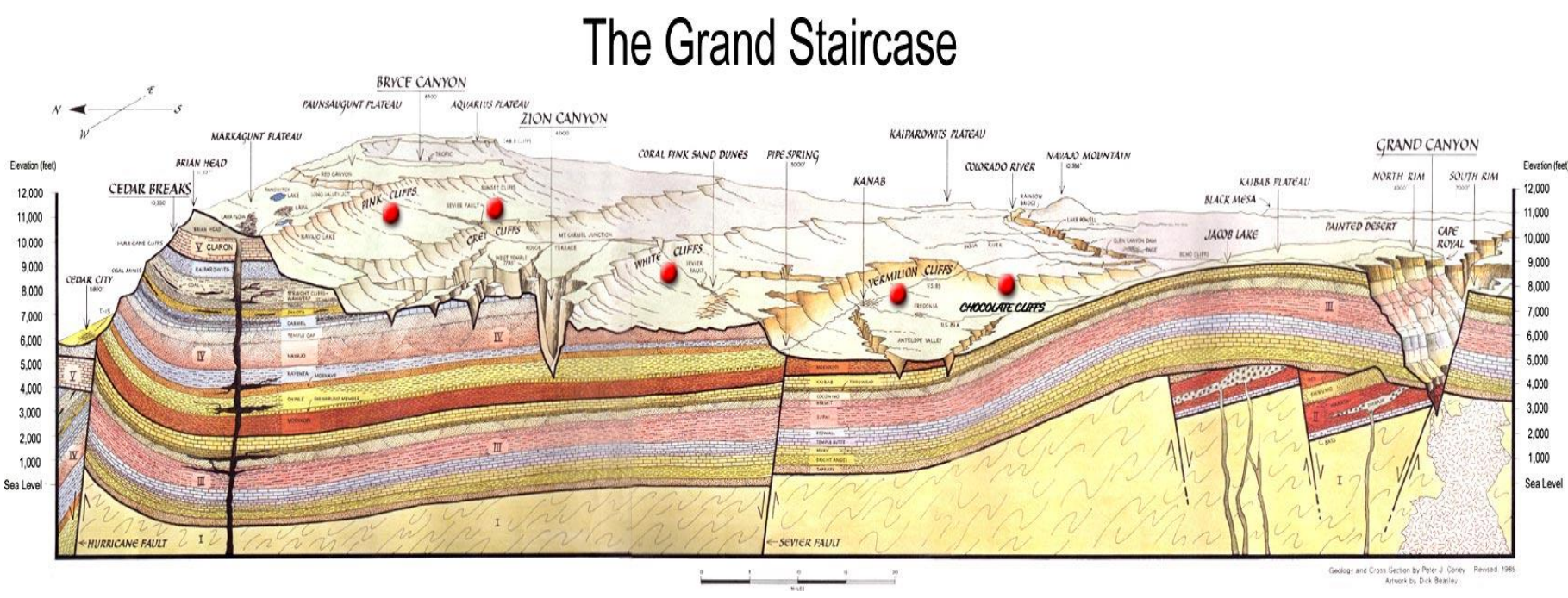

Fig 2. Cross section illustrating the link between the sedimentary deposits of the Grand Canyon and the Grand Staircase leading up to Bryce Canyon. It graphically illustrates the km scale uplifts that have occurred in the past 40Ma and the erosion of the post $-270 \mathrm{Ma}$ sediments from the Grand Canyon area.

\section{RELATING PHASES OF DEPOSITION TO CLIMATE CYCLES}

Fig 3 summarises the pulses in deposition for which the most robust temporal signal is the commencement of deposition following a hiatus in which there was either no sedimentation occurring or erosion has removed the evidence of any sedimentation that had occurred. It is clear that at the intra-cratonic location of the Grand Canyon, subsidence below sea level, likely combined with moderate rises in sea level, and the start of new pulses in sedimentation occurred over the Phanerozoic at $-525 \mathrm{Ma},-385 \mathrm{Ma},-265 \mathrm{Ma}$, and -140 Ma; there are further hiatus at $-340 \mathrm{Ma}$ and 240Ma. These ages of sediments immediately above unconformities are well defined and consequently marked with strong black lines on, the bar chart of pulses of deposition of Fig 3 . When sedimentation ceased or when erosion started are rather less well defined and so are marked with decreasingly dense lines on the bar charts.

Also plotted in Fig 3 are the geological reconstructions of the average surface temperatures over this same time period ${ }^{8}$ along with predictions of surface temperatures based upon analysis of the variations in cosmic ray flux ${ }^{9}$ experienced by the solar system. What is noteworthy in these plots are: 
the close, and possibly causa $\left.\right|^{8,9}$, relationships between the intensity of cosmic rays and climate cycles, and; the strong correlation between the onset of deposition as recorded by strata immediately above recorded major unconformities and their consistent phasing within the climate cycles. In each case, deposition is seen to commence shortly after earth climate emerges from an ice-house period, shown by one of the upper bars in Fig 3, and enters into a period of hot house. After a long period of glacial and inter-glacial cycles during the ice-house period, it might be anticipated that ice erosion will have reduced continental land surface elevations in the vicinity of ice sheets to near sea level. This means that moderate rises in average sea levels, due to the melting of ice sheet and permafrost accompanying the transition from average cold climate to hot-house, might be expected to inundate the low continental land surfaces - a clear precondition for the onset of marine sedimentation.

A possible explanation as to how the transition from ice-house to hot-house conditions could trigger an extended period of sedimentation has focused on the adjustments to the geothermal flux occurring when low lying continental crust is inundated by rising sea levels as global ice sheets and extensive permafrost melts ${ }^{13,14}$. This is summarised in Fig B.1 of Appendix B. Increases in the geothermal heat flux caused by the greater heat transfer capacities of sea water, enhanced by mixing due to tides and currents, would over time result in steeper geothermal gradients and a concomitant decrease in crustal thickness brought about by phase change, re-magmafication, at the lower lithosphere-mantle boundary. This crustal thinning will result in an increase in average density within the lithosphere and upper mantle which in turn would be expected to result in regional subsidence of the crust. Such a model, involving as it does wasting of crust at the lower lithospheremantle boundary, starts to account for how km scale sedimentary sequences can be continuously added from above. As suggested, this requires maintenance of a consistent equilibrium thermal gradient even as sediments are added - a process much more likely given the relatively thin nature of oceanic crust.

\section{RELATING EPEIROGENY TO CLIMATE CYCLES}

Previous studies have noted the close link between periods of mountain building with climate cycles $^{14,15,16}$. Recorded periods of mountain building ${ }^{13}$ are summarised by the bar charts at the top of Fig 3. The 4 recorded periods of widespread mountain building during the Phanerozoic, often occurring synchronously over widely dispersed geographical domains, are shown to correspond closely with the periods of ice-house climate conditions. Tentative explanations for how ice-house conditions could result in spurts of uplift required for mountain building and subsequent erosion have again focused on how changes in surface disposition of ice and water could influence the rate of geothermal heat loss as expressed by the geothermal flux ${ }^{13,14}$. Reductions in the geothermal heat flux caused by the insulating effects of the development of deep surface ice sheets and permafrost would result in a lowering of the geothermal gradient and a concomitant increase in crustal thickness brought about by aggradation, caused by phase change, at the lower lithosphere-mantle boundary. Associated reductions in average density within the lithosphere and mantle could then be expected to result in regional uplift of the crust. This is summarised in Fig B.2 of Appendix B. 


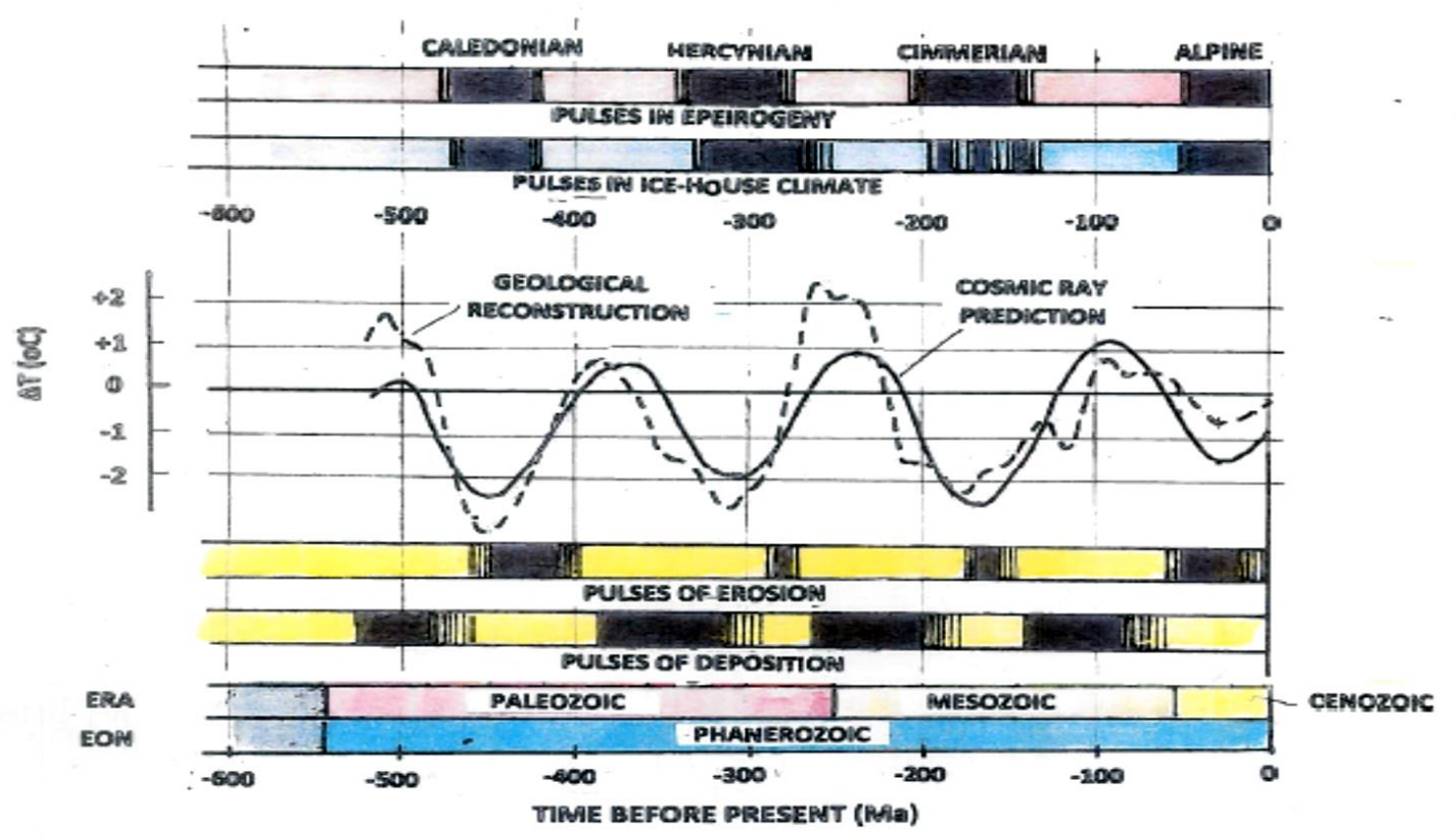

Fig 3 Cycles of average earth surface temperatures over the Phanerozoic showing the correlation between: 1 . the onset of ice-house periods and pulses of epeirogenic uplift (upper bar charts); and 2. the onset of hot-house periods and pulses of deposition.

\section{DISCUSSION}

This brief note has concentrated on the sedimentary sequences of the Grand and Bryce Canyon areas simply because they are so clearly exposed and thoroughly researched. Furthermore, as the stratigraphic geometry shown in Fig 2 explicitly demonstrates, the Grand Canyon area in particular has recently, and certainly post breakup, been subject to major uplift and ice erosion. Earlier sequence stratigraphy suggests that this area has been subject to repeated cycles of ice- and hothouse climate cycles and consequently the direct correlation of tectonic activity and climate. But clearly the massive erosion occurring during the ice-house phases must produce in contiguous areas equally massive accumulations of ice erosion deposits, suggesting a counter-phasing of deposition in areas contiguous with those directly affected by the growth of ice-sheets - and of course vice versa during the erosion of possibly uplifted areas during hot-house climatic conditions.

From the direct evidence of the Grand Canyon, along with the reported synchronicity over cratonwide and even continent wide areas noted by Sloss and others, there appears to be strong evidence of a causal link between cycles of uplift and erosion during ice-house global climate, and subsidence and deposition during hot-house climatic conditions. It is therefore surprising that the thermogeodynamics underpinning these links have not been more thoroughly investigated. If as suggested there is a causal link between at least vertical tectonics and global climate cycles this could significantly add to our ability to explain other important aspects of global tectonics. While current mobilist concepts seek to explain evidence of changing climatic domains within the sedimentary record through latitudinal continental movements, to largely conform with contemporary global climate, it is possible that these same sedimentary records could equally well be explained by a fixist view of contemporary continental locations subject to the long term climate cycles discussed above or perhaps a bit of both.

\section{CONCLUDING REMARKS}

A reconstruction of the sedimentation records of the Grand Canyon region reveals a strong correlation between the timing of the recommencement of deposition cycles above major 
unconformities and the transition from global ice-house climates to hot-house. This has been explained in terms of sea level rises accompanying the melting of surface ice. Ocean currents and tidal flows provide a more effective heat transfer mechanism for the outflow of geothermal heat energy. An adjusted geothermal gradient resulting from the increased geothermal heat flux has the effect of thinning the crust, through a process of phase change, re-magmafication, at the lower crust boundary. Increased average density of the crustal column will then result in continuing subsidence as sediment is added from above and lower crust removed. This circa $130 \mathrm{Ma}$ cycle of pulses in sedimentation in phase with the onset of hot-house climate conditions appear to be related to similarly timed pulses of uplift and mountain building observed to coincide with the onset of icehouse periods.

With hot- and ice-house conditions known to have had global reach starts to explain the often noted synchronicity of burial and exhumation events over widely dispersed geographic domains and often remote from any active tectonic zones. Furthermore, high levels of temperature change at a given crustal depth, associated with the periodic thickening and thinning of crust, will induce massive cycles of horizontal thermal strain and deformations. Restraint, of these thermally induced strains could in turn account for many of the observed fracture patterns during tension cycles, or folding and metamorphism during compression cycles.

\section{References:}

1. William Smith Meeting 2017: Plate Tectonics at 50, Geological Society London, 3 October, 2017. https://www.geolsoc.org.uk/wsmith17

2. Green, $\mathrm{P}$ et alia (2017) Kilometre-scale burial and exhumation of passive margins and continental interiors: an overlooked consequence of plate tectonics? Paper presented in session 8, William Smith Meeting 2017: Plate Tectonics at 50, Geological Society London, 3 October, 2017

3. Green, $\mathrm{P}$ et alia. Post-breakup burial and exhumation of passive continental margins: Seven propositions to inform geodynamic models, Gondwana Research, 53 (2018), 58-81.

4. Hutton, J (1795) Theory of the Earth, vol. 1, Edinburgh.

5. Sloss, LL, Krumbein, WC, Dapples, EC (1949) Integrated facies analysis, appearing in Longwell, CR, Sedimentary facies in geological history, GSA Bulletin, 39, 91-124.

6. Sloss, LL (1963) Sequences in the cratonic interior of North America, GSA Bulletin, 74, 93-114.

7. Sloss, LL (1964) Tectonic Cycles of the North American Craton, in Symposium on cyclic sedimentation: Kansas Geological Survey, ed. Merriam, D. F., Bulletin 169, 449459.

8. Shaviv, N. J. and Veizer, J. (2003): Celestial driver of Phanerozoic climate? GSA Today, July, 4-10.

9. Shaviv, N. J. (2002): The spiral structure of the milky way, cosmic rays, and ice age epochs on Earth, New Astronomy, 8, 39-77.

10. Beus, S. S. and Morales, M. (ed) (2003) Grand Canyon geology, NY: Oxford University Press, $2^{\text {nd }}$ Edition, see contributions from Beus, S. S., Blakey, R. C. et alia.

11. Timmins, J. M. and Karlstrom, K. E. (ed) (2012) Grand Canyon geology: Two biion years of Earth's history, GSA Special Paper 489, see contributions from Blakey, R. C., Middleton, L. T., Timmons, J. M., Karlstrom, K. E. et alia. 
12. Sprinkel, D. A., Chidsey, D. C., Anderson, P. B. (ed) (2003) Geology of Utah's parks and monuments. Utah Geological Association Publication 28, $2^{\text {nd }}$ Ed., see paper by Sprinkel, D. A.

13. Croll, J. G. A. (2007): A new hypothesis for Earth lithosphere evolution, New Concepts in Global tectonics, Newsletter, 45, December 34-51.

14. Croll, J G A (2011) Some Comments on Lithosphere Evolution, paper presented at Frontiers Meeting, Geological Society London, 14 November, 2011.

15. Illis, B. (2009): Searching the Paleo Climate record for estimated correlations: temperature $\mathrm{CO} 2$ and sea level, see Kalenda et al..

16. Kalenda, P, Neumann et al. (2011) Tilts, global tectonics and earthquake prediction, research monograph, in press. 


\section{APPENDIX A}

Reconstructions of the cycles of subsidence and sedimentation followed by uplift and erosion

amsl = average mean sea level

numbers to right $=$ Ma before present

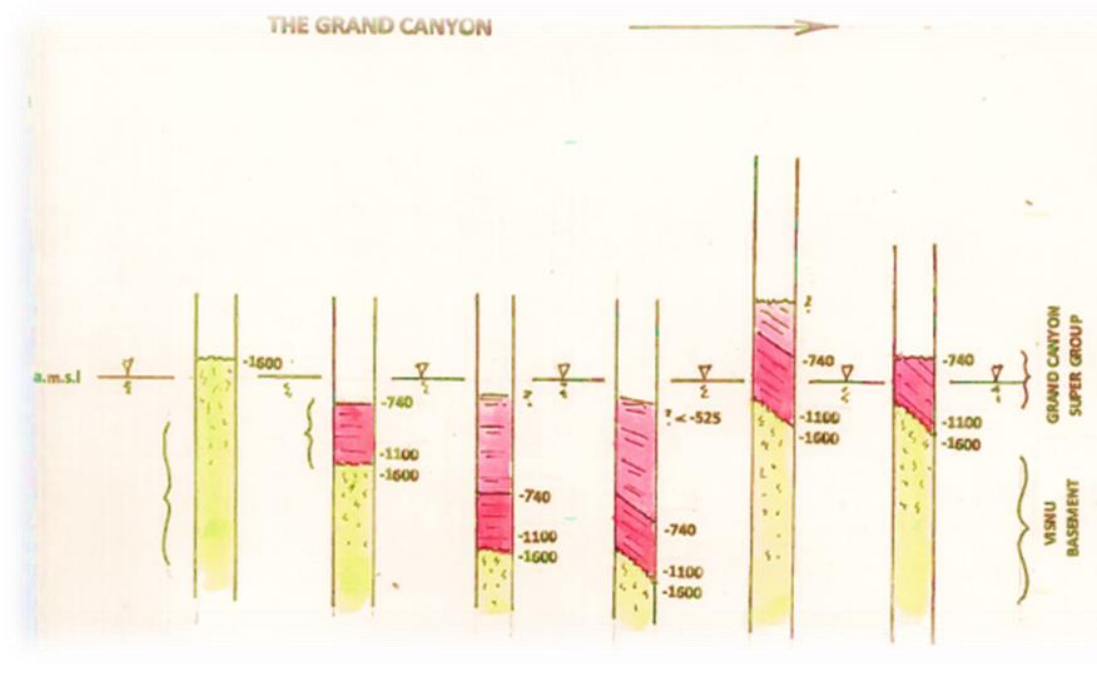

$\begin{array}{lllll}\text { (a) } & \text { (b) } & \text { (c) } & \text { (d) } & \text { (e) }\end{array}$

Fig A.1 From left to right shows (a) an eroded Visnu basement subsiding beneath average mean sea level and having from - $1100 \mathrm{Ma}$ sediments of the Grand Canyon Supergroup deposited until (b) at least -740 Ma and (c) some unknown time prior to $-525 \mathrm{Ma}$ of depth sufficient to cause (d) tectonic distortion before (e) uplift and (f) erosion back to a peneplain with youngest exposed sediments $-740 \mathrm{Ma}$

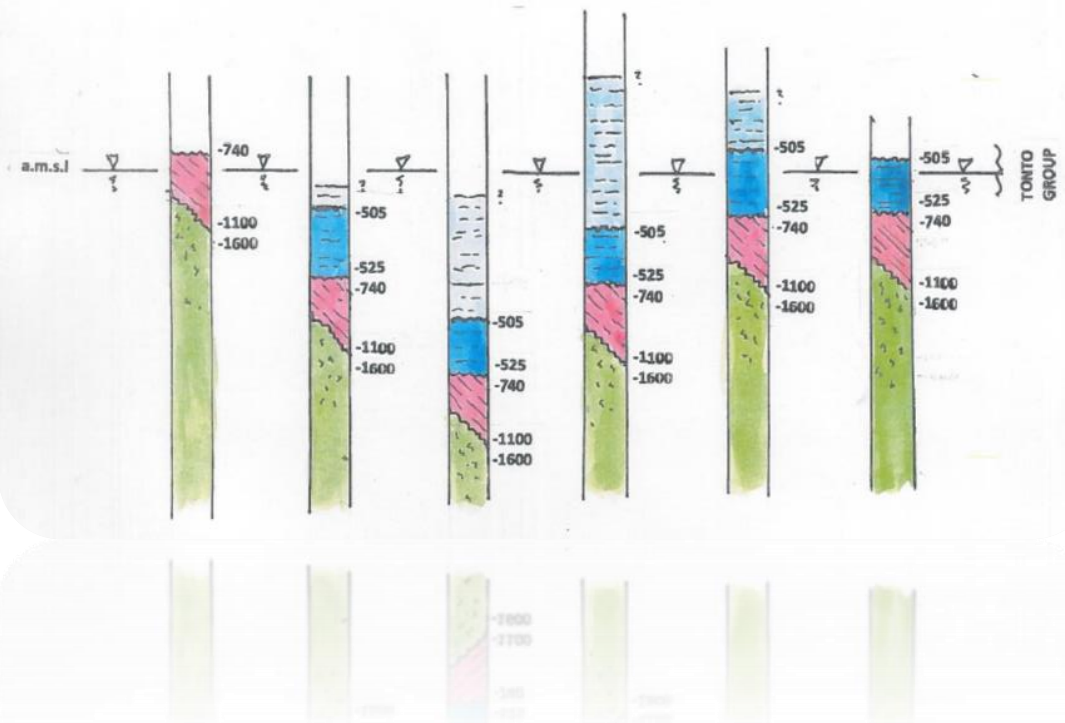

a)

(b)

(c)

(d)

(e)

(f) 
Fig A.2 From left to right shows (a) an eroded Grand Canyon Supergroup subsiding beneath average mean sea level and having from - 525 Ma sediments of the Tonto group deposited until (b) at least -505 Ma and (c) some unknown time prior to -385 Ma before (d) uplift and erosion continuing (f) to a peneplain with youngest exposed sediments -505 Ma.

THE GRAND CANYON

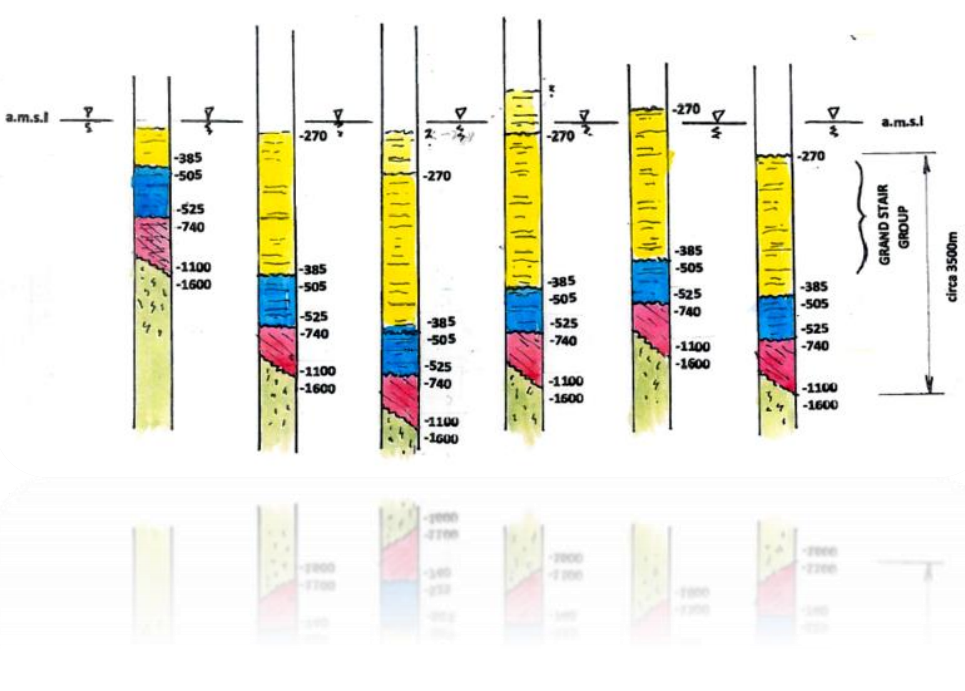

$\begin{array}{lllll}(a) & \text { (b) } & \text { (c) } & \text { (d) } & \text { (e) }\end{array}$

Fig A.3 From left to right shows (a) an eroded Tonto group subsided beneath average mean sea level and having from -385 Ma sediments of the Grand Stair Group deposited until (b) at least -270 Ma and (c) some unknown time prior to -260 Ma before (d) uplift and erosion continuing $(\mathrm{f})$ to a peneplain with youngest exposed sediments $-270 \mathrm{Ma}$ in the area of the Grand Canyon.

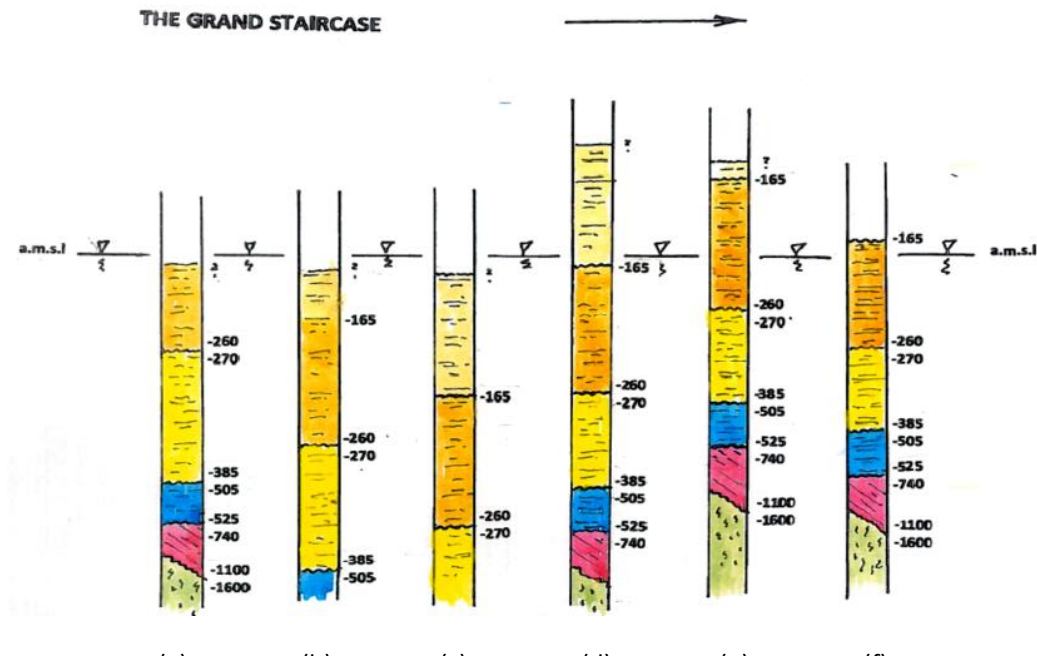

(b)

(c)

(d)

(e)

(f)

Fig A.4 From left to right shows (a) an eroded Grand Stair Group subsided beneath average mean sea level and having from -265 Ma sediments of the Grand Stair Group deposited until (b) at least -165 Ma and (c) some unknown time prior to -140 Ma before (d) uplift and erosion continuing (f) to a peneplain with young exposed sediments $-165 \mathrm{Ma}$. 


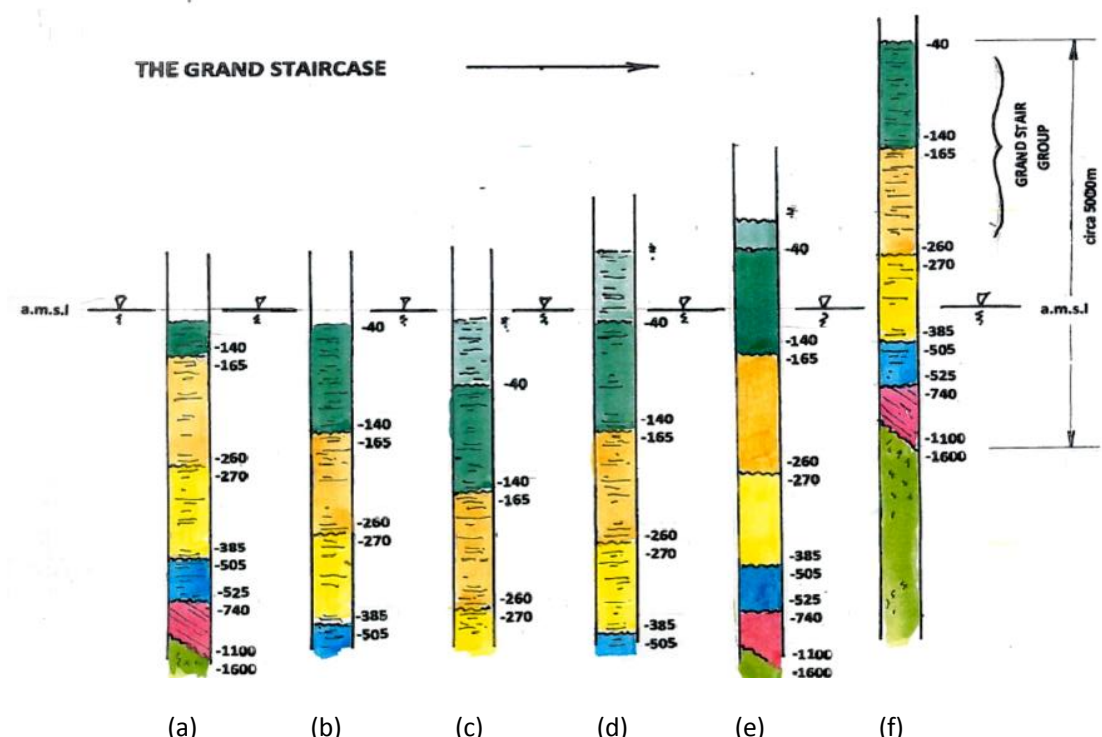

Fig A.5 From left to right shows (a) an eroded Grand Stair Group subsided beneath average mean sea level and having from -140 Ma further sediments of the Grand Stair Group deposited until (b) at least -40 Ma and (c) some unknown time prior to present before (d) uplift and erosion continuing (f) to form the outcrops of the Grand Staircase with youngest exposed sediments -40 Ma.

\section{APPENDIX B}

\section{Geothermaal mechanism for epeirogenic subsidence and uplift}

To aid visualisation of isostacy these crustal columns are drawn relative to the mean magmatic level $(\mathrm{mml})$ - the free surface of an idealised magmatic fluid.

GEOTHERMAL MECHANISM FOR SUBSIDENCE (BURLAL) (and onset of sedimentation)

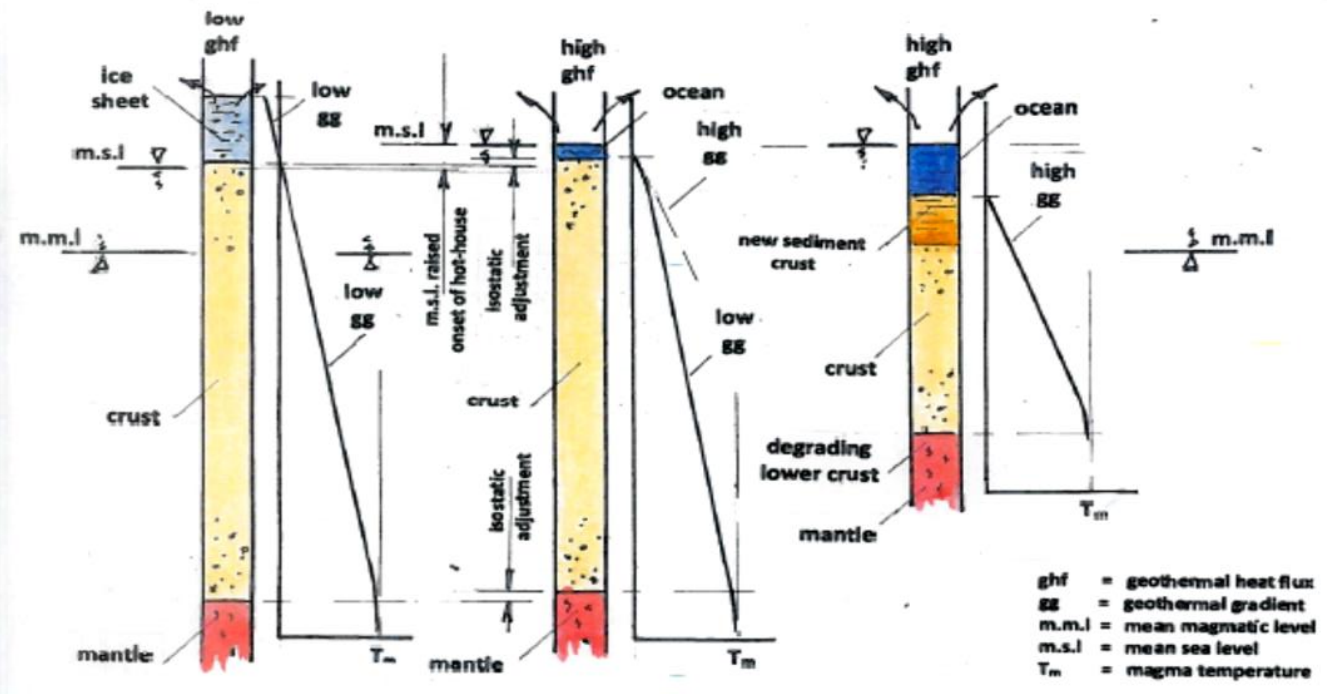

(a)

(b)

(c)

Fig B.1 Mechanism for epeirogenic subsidence and sediment accumulation based upon (a) the low geothermal gradient due to insulation effects of overlying ice-sheets and permafrost during ice-house conditions which with (b) rise in mean sea level after transition to hot-house climate floods upper surface of the crust which over a few Ma (c) readjusts to a higher geothermal gradient and decreased crustal thickness through degradation of lower crust allowing accumulation of sediments from above. 


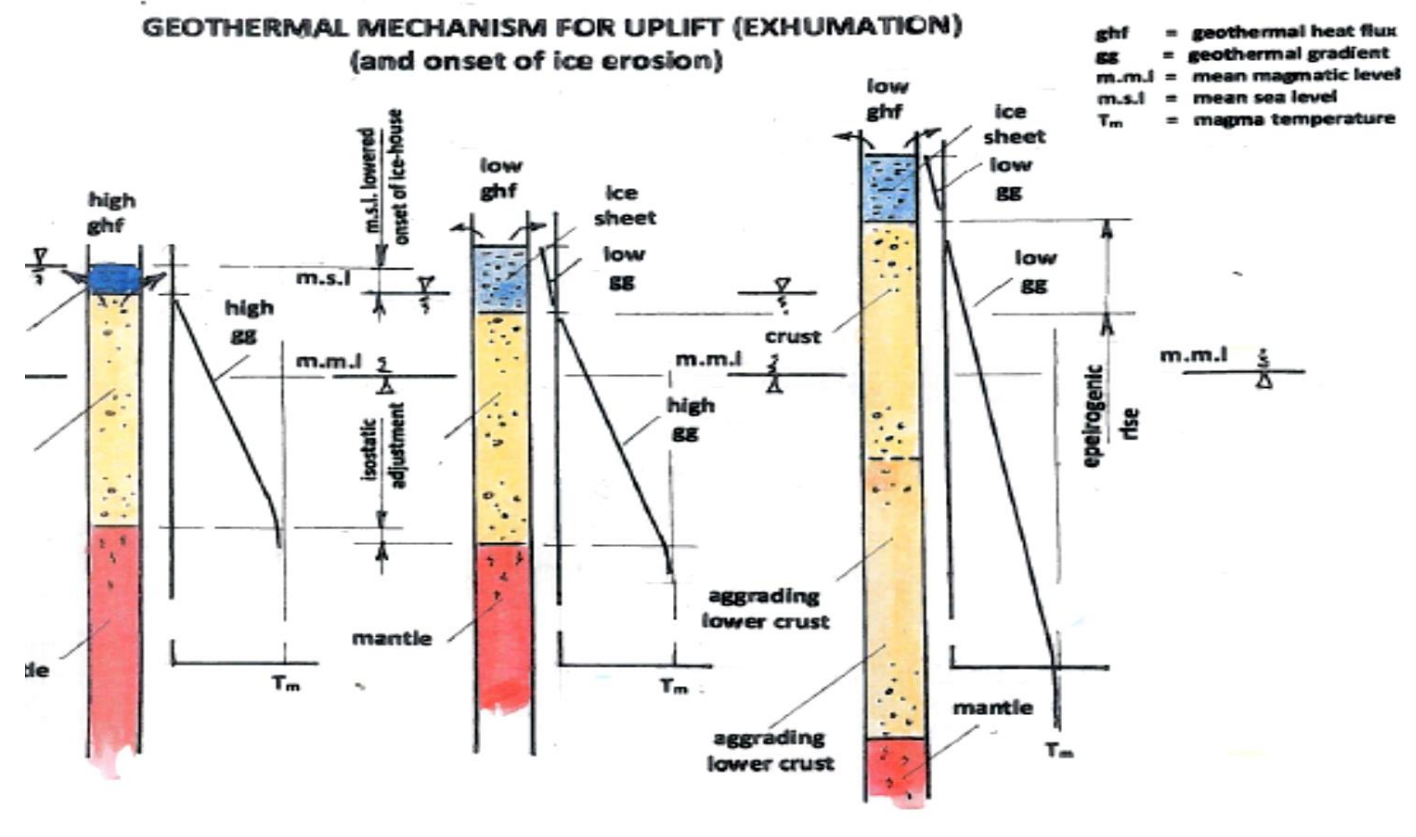

(a)

(b)

(c)

Fig B.2 Mechanism for epeirogenic uplift and sediment erosion based upon (a) the high geothermal gradient due to high heat flux into the overlying ocean during hot-house conditions which with (b) the development of thick ice-sheets and permafrost after transition to ice-house climate reduces the geothermal heat flux which over a few Ma (c) readjusts to a lower geothermal gradient and increased crustal thickness through aggradation of lower crust while crust continues to rise during ice erosion. 